\author{
Dermatology \\ Psychosomatics \\ Dermatologie \\ Psychosomatik
}

Dermatol Psychosom 2001;2:108-109

\title{
Transdisciplinarity - an Essential Prerequisite for Psychodermatological Healing
}

During the past 2 or 3 decades, medical research has made enormous progress. It has made possible an increasingly fine comprehension of the physiopathological mechanisms underlying many diseases. However, in this process the human being has been reduced to a functional - or dysfunctional - accumulation of cells. Psychic suffering was separated from the rest of the human being and was confined to the cabinets of psychiatrists, or the couches of psychoanalysts. The numerous qualityof-life questionnaires recently developed [1-3] have called to attention the previously unnoticed suffering related to chronic cutaneous diseases. A dermatologist is confronted with a wide variety of disorders in which the psychic suffering is obvious, as either cause or consequence. The list is long and includes diseases as diverse as severe atopic dermatitis, generalized psoriasis, alopecia areata universalis, neurotic excoriations, factitious disorders, delusions of parasites, body dysmorphic disorders, and acne excoriée. Often he is overwhelmed with these cases as he was not prepared for them. Sending the patient to a psychiatrist is often not easy because usually the patient does not ask for it and sometimes is even very reluctant to assent. And dermatological care must still be provided. In the work of Musalek et al. this difficulty as well as the necessity for a clear classification of psychodermatological disorders for effective treatment is illustrated.

A close collaboration of dermatologists and psychiatrists or a specific psychodermatology training could enable dermatologists to take better care of patients suffering from psychodermatological disorders. In this context, I appreciated very much the case report presented by Niemeier et al. about glossodynia. Like them I often felt that I have to express the feelings and emotions in place of the patient who is unable to put them into words. The transference-countertransference analysis presented by them will help the reader to be clearer in similar cases often encountered in psychodermatology.
The very good statistical study about anxiety, aggression, and body ideal in atopic dermatitis patients presented by Linnet and Jemec will also help to convince dermatologists that a global approach is much more helpful than dermatological care alone. The article of Radmanesh and Shefiei about psychogenic pruritus points out the important role of transdisciplinary cooperation as well: They show that all their patients with psychopruritic skin disorders had an underlying psychiatric disorder, mostly anxiety or depressive disorders.

Stress management training for young atopic dermatitis patients together with education in dermatological care as proposed by Hampel and her colleagues is a way to alleviate the psychic suffering of dermatological patients. It underlines the benefits of atopic dermatitis management programs, like the standardized programs in Germany [4]. As the authors developed a similar program for young psoriatic patients [5], it stands to hope that other studies will bring forth programs for different psychocutaneous conditions and in more countries. We have in this issue two letters to the Editors: The observations of Zrnic et al. about psoriatic onset and recurrences in the population during the war in Bosnia is confirming the connection between stressful life events and psoriasis. Similar findings were published concerning soldiers in that war [4]. The letter by Cohen focuses on the difficulties for babies born with blistered epidermolysis to constitute their 'Ego-Skin', a very important step in development. The author suggests to replace physical caresses, which are made impossible by the disease, with music and the caress of the mother's voice. It is important to stress that dermatologists should be aware of what is going on in the unconsciousness of those babies to prevent 'psychic scars' as far as possible.

All these articles show how much collaboration between psychiatrists, psychologists and dermatologists is needed. Transdisciplinary meetings are essential so that we, the healers, can

\begin{tabular}{ll}
\hline KARGER & @ 2001 S. Karger GmbH, Freiburg \\
Fax +497614520714 & Accessible online at: \\
$\begin{array}{l}\text { E-mail Information@Karger.de } \\
\text { www.karger.com }\end{array}$ & www.karger.com/journals/dps
\end{tabular}


help the patient to understand the complex meaning of the cutaneous symptoms so he can finally free himself from it, or, when that is not possible, to develop adapted coping strategies and reduce the psychic suffering. In this issue of DERMATOLOGY + PSYCHOSOMATICS you can verify and increase your psychodermatological knowledge with the quiz prepared by Höring and Nist.

As a new member of the Editorial Board I am very happy to have the possibility to work actively in developing the scientific settlement and the rising of this new worthwhile part of the medical science called psychocutaneous medicine, psychosomatic dermatology, or psychodermatology.

Françoise Poot, Brussels

\section{References}

1 Augustin M, Zschocke I, Seidenglanz K, Lange S, Schiffler A, Amon U: Validation and clinical results of the FLQA-d, a quality of life questionnaire for patient with chronic skin diseases. Dermatol Psychosom 2000;1:12-17.

2 Chren MM, Lasker RJ, Quinn LM, Covinsky KE: Skindex, a quality-of-life measure for patients with skin diseases: Reliability, validity and responsiveness. J Invest Dermatol 1996;107:707-713.

3 Finlay AK, Kahn GK: Dermatology Life Quality Index (DLQI): A simple practical measure for routine clinical use. Clin Exp Dermatol 1994;19:210-216.

4 Gieler U, Kupfer J, Niemeier V, Brosig B, Stangier U: Atopic eczema prevention program - a new therapeutic concept for secondary prevention. Dermatol Psychosom 2000;1:138-147.

5 Hampel P, Peterman F, Schmidt S, Scheewe S, Stachow R: Cognitive behavioural stress management as an integrated module of patient education for children and adolescents with psoriasis: First results. Prävention Rehabil 1999;11:37-46.

6 Suljagic E, Sinanovic O, Tupkovic E, Moro L: Stressful life events and psoriasis during the war in Bosnia. Dermatol Psychosom 2000;1:56-60. 